\title{
TANULÁSI UTAK A TÁRSADALMI HÁTTÉR FÜGGVÉNYÉBEN
}

\author{
HÖRICH BALÁZS
}

Debreceni Egyetem, Humán Tudományok Doktori Iskola

\begin{abstract}
A tanulmányban a közoktatásban részt vevő tanulók tanulási útjait mutatom be két tipizálási logika mentén. Egyrészt a tovább haladás folytonosságát, másrészt a teljesítmény és a társadalmi háttér alapján kialakított tanulócsoportok pályaútját követem a 6. évfolyamtól a 10. évfolyamig. A bináris logisztikus regresszióelemzés rámutatott arra, hogy a vizsgált tanulócsoportok markánsan különböznek egymástól intézményi háttér, teljesítmény, szociális háttér, tanulási nehézségek és származási jellemzők szerint. Az egyes csoportok között a középfokú továbbhaladás irányait tekintve is nagy eltérések láthatók, ráadásul ezeket inkább a társadalmi háttérre, mintsem a teljesítményre lehet visszavezetni. Az elemzés alapját az Országos Kompetenciamérés 2011-2017. éves felméréseinek összefüzött tanulói adatbázisa adja.
\end{abstract}

Kulcsszavak: tanulási utak, közoktatás, társadalmi háttér, lemorzsolódás, reziliencia, OKM

In the study, I present the learning paths of learners taking part in public education along two categorisational logics. On the one hand, I follow the continuity of progress, and on the other hand, the paths of groups based on performance and social background from grade 6 to grade 10. The binary logistic regression analysis showed that the study groups differed significantly in terms of institutional background, performance, social background, learning difficulties and (characteristics of) origin. There are also large differences between the groups regarding the direction of secondary education, which can be traced back to the social background rather than the performance. The bases of the analysis are the linked student databases of Hungarian National Assessment of Basic Competencies 2011-2017.

Keywords: learning paths, public education, social background, drop-out, resilience, NABC 
A $z$ iskolai szelekció a teljesítmény és a társadalmi háttér szerint a tanulási út elágazási pontjain egymástól eltérő irányokba tereli a tanulókat. Kitüntetett szelekciós pont a beiskolázás, az általános képzésből a középfokú képzésbe, illetve a középfokú képzésből a felsőoktatásba történő váltás, ám utóbbi elágazások az esetek nagy részében csak „szentesítik” az általános iskola alsó és felső tagozatán jelentkező tanulói differenciáltságot. A magyar oktatási rendszer a tanulási út korai szakaszában szelektál és egyúttal komoly méltányossági problémákat is felvet. A méltányos oktatás lényege, hogy származásától, társadalmi-gazdasági státuszától függetlenül mindenkinek lehetőséget kell biztosítani vágyainak, elképzeléseinek és képességeinek megfelelő kibontakoztatásra (Révai 2015). A méltányossági megközelítés így a kimeneti mutatókra, indikátorokra fókuszál (Papp 2015). A tanulók társadalmi-gazdasági helyzete a mért teljesítményterülettől függetlenül minden oktatási rendszerben meghatározza a tanuló teljesítményét (OECD 2010, 2013), de a magyar oktatási rendszer ezen a téren különösen kedvezötlen helyzetben van (OECD 2016).

A társadalmi háttér és a tanulói eredményesség szoros kapcsolatára több hazai kutatás is rámutatott (Andor-Liskó 1999; Kertesi-Kézdi 2010; Balázsi et al. 2014), tanulmányommal e kutatások sorához kívánok igazodni. Az elemzői adatbázis kialakításának ismertetését követően két logika mentén vizsgálom az egyéni tanulási utakat. Az első logika szerint a továbbhaladás folyamatosságát vizsgálom meg, a második szerint a társadalmi háttérnek és a tanulók teljesítményének figyelembevételével kialakított tanulói csoportok későbbi útjait vizsgálom.

A tanulók egyéni tanulási útjának nyomon követésére alapvetően három mód kínálkozik. Egyrészt támaszkodhatunk a köznevelés információs rendszerének tanulói nyilvántartására, ami tanulónként rögzíti, hogy mely évben, iskolában, évfolyamon, milyen jogviszony szerint (stb.) tanult valaki, ha pedig jogviszonya véget ért, az milyen okokra vezethető vissza. ${ }^{1} \mathrm{Ez}$ az adatbázis azonban kutatási célokra nem, vagy csak nagyon korlátozott módon használható föl. Az egyéni tanulói nyomon követés másik lehetősége, ha többéves időszakot átívelő panelkutatást végzünk, ugyanakkor e felmérésekre financiális okokból viszonylag ritkán kerül sor. Az egyik utolsó ilyen kutatás a TÁRKI Életpálya-felmérése volt (Hajdú-Kertesi-Kézdi 2014). A harmadik lehetőség, ha az Országos Kompetenciamérés (OKM) az Oktatási Hivatal által kutatási célokra bocsátott adatbázisait dolgozzuk föl (Szemerszki 2016).

Jelen másodelemzést ez utóbbi lehetőség biztosítja. A kompetenciamérések a 6 , a 8. és a 10. évfolyamokon kerülnek megszervezésre, intézménytípustól függetlenül, a tanulók teljes populációját bevonva (leszámítva a mentességet élvezőket ${ }^{2}$ ). Az OKM elsősorban a szövegértési és matematikai készségek tanulói vizsgálatára fókuszál, ám három kiegészítő kérdőív is tartozik hozzá: az ún. intézményvezetői kérdőívet az oktatási intézmények vezetői, az ún. telephelyi kérdőívet az intézmények alá tartozó feladatellátási helyek irányítói kötelezően, az ún. tanulói kérdőívet pedig a mérésben részt vevő tanulók, illetve szüleik önkéntes alapon töltik ki. A mérési eredmények és a háttérkérdőívek fel-

1 Az adatbázisban érintettek és a kezelt adatok köréről a 2018. évi LXXXIX. törvény rendelkezik, részletesebb leírás az Oktatási Hivatal honlapján található (https://www.oktatas.hu/hivatal/kozerdeku_adatok/ kir_szemelyi_nyilvantartas).

2 Értelmi fogyatékos vagy autista tanulók, valamint az olyan mértékű mozgásszervi, érzékszervi vagy beszédfogyatékossággal rendelkező, sajátos nevelési igényủ tanulók, akiket fogyatékosságuk megakadályoz a teszt kitöltésében (OH 2012). 
használásával évfolyamonként összesen három kutatói adatbázis készül el az Oktatási Hivatalban. Az intézményi adatbázisban az intézményi háttéradatok, illetve az intézményre összesített mérési eredmények szerepelnek; a telephelyi adatbázisban a telephelyekre vonatkozó háttéradatok és összesített mérési eredmények találhatók; a tanulói adatbázisban pedig az egyéni eredmények és a tanulói kérdőív válaszai érhetők el. Utóbbi adatbázisban a tanulók anonimizált módon, egyedi azonosítószámmal szerepelnek. Az azonosítók az egymást követő mérések során megegyeznek, így lehetővé válik egy-egy tanuló nyomon követése. Ennek eredményeképpen vizsgálható, miként változott a teljesítmény, változtak-e a családi körülmények, illetve hogyan alakult az egyéni tanulmányi út. Azok a tanulók is bekerülnek a tanulói adatbázisba, akik egy adott évfolyam kompetenciamérésén nem voltak jelen vagy nem töltötték ki a tesztfüzetet; esetükben ugyan mérési adatok nincsenek, de az alapadatok elérhetők.

A tanulói adatbázisok összekapcsolásával tehát tanulónként felrajzolható, mely intézményben (feladatellátási helyen) és melyik tanévben tanult a 6., a 8. és a 10. évfolyamon, ezen időszak alatt melyik évfolyamon és hányszor történt évismétlés, illetve az is, megszakadt-e a tanulmányi út valahol a 10. évfolyamon az év vége előtt.

\section{Az elemzői adatbázis kialakítása}

Az elemzői adatbázis alapját a 2011., 2012., 2013., 2014., 2015., 2016. és a 2017. évi 6., 8. és 10. évfolyamos tanulói OKM adatbázisok összekapcsolásával alakítottam ki (1. táblázat). A 2011. évi bázisév adataihoz először a 2012-2017. évi, ugyancsak 6. évfolyamos tanulói adatbázisait kapcsoltam (a végleges adatbázisban így megjelentek 2011 utáni, 6. évfolyamon évismétlők is), majd a 2013-2017. évi 8. évfolyamos tanulói adatbázisokat füztem hozzá (ezzel bekerültek azok, akik folyamatos előrehaladással jutottak el a 8. évfolyam végéig, illetve azok, akik 2013 előtt a 6. évfolyamon legalább egyszer, 2013-ban vagy azt követően a 8. évfolyamon évet ismételtek). Végezetül az így felépített adatbázishoz a 2015., 2016. és 2017. évi 10. évfolyamos tanulói adatbázist kapcsoltam.

\section{1. táblázat: A vizsgálatba bevont OKM tanulói adatbázisok}

\begin{tabular}{lccc}
\hline Év & 6.évfolyam & 8. évfolyam & 10. évfolyam \\
\hline 2011 & X & & \\
2012 & $X$ & & \\
2013 & $X$ & $X$ & \\
2014 & $X$ & $X$ & \\
2015 & $X$ & $X$ & $X$ \\
2016 & $X$ & $X$ & $X$ \\
2017 & $X$ & $X$ & $X$ \\
\hline
\end{tabular}

Az elemzői adatbázisban összesen 94047 tanuló adata szerepel. Az adatbázis összeállítása során arra törekedtem, hogy az elérhető adatok mennyiségét maximalizáljam: éppen emiatt a tanulói kérdőívek válaszait - ahol a vizsgált kérdés és az alkalmazott módszer ezt indokolja és lehetővé teszi - az utolsó adatközlés szerint vettem figyelem- 
be (a későbbiekben visszapótló eljárásként hivatkozom erre a metódusra). Bizonyos kérdések esetében ez a módszer magában hordozza a torzítás veszélyét, hiszen időközben előfordulhatnak a válaszok tárgyában észlelhető változások, ám az esetek meghatározó részénél ennek veszélye mégiscsak csekély, ráadásul az adatbázis robusztussága korlátokat szab a komoly statisztikai torzításnak is.

\section{A tanulók elörehaladása}

A 2011-ben 6. évfolyamos kompetenciamérésen részt vevők 98 százaléka még ebben az évben elvégezte a 6. évfolyamot. Az évfolyamismétlésre kötelezettek zöme (84 százaléka) ezt követően ${ }^{3}$ már csak egyszer járta újra a hatodik osztályt. 2013-ban a bázisév (2011) hatodik évfolyamos tanulóinak 94 százaléka végezte el a nyolcadik évfolyamot, a következő évben pedig további 2 százaléka (2. táblázat). Azok, akik 2011-ben hatodik évfolyamban évismétlésre voltak kötelezve, azaz 2012-ben is ebben az évfolyamban ragadtak, többségükben (53\%) már nem végezték el később sem a nyolcadik évfolyamot - a minél későbbi továbbhaladás egyúttal a lemorzsolódás (a nyolcadik évfolyam el nem végzésének) valószínűségét növeli. A bázisév hatodik évfolyamosait összesítve minden huszadik tanulóra (5\%) jellemző, hogy nincs 8. évfolyamos kompetenciamérési-bejegyzése.

2. táblázat: Előrehaladás hatodik és nyolcadik évfolyam között, \% $(N=94047)$

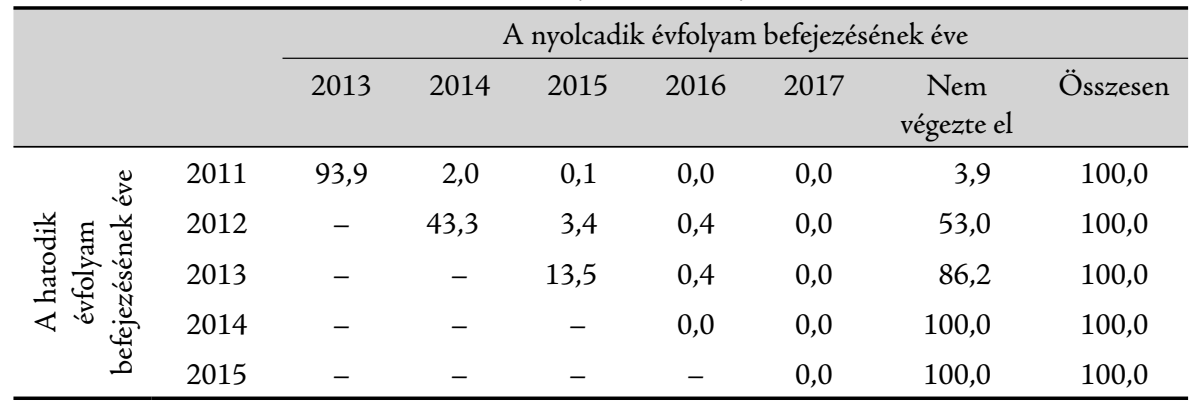

A 2013-ban nyolcadik évfolyamos kompetenciamérésen részt vevők 11 százaléka nem vett részt sem a 2015, sem a 2016,, sem pedig a 2017. évi 10. évfolyamos mérésen (3. táblázat). A hogy a hatodik és nyolcadik évfolyam közötti átmenetnél látható volt, a nyolcadik és tizedik évfolyam között is jellemző, hogy minél későbbi évben végezte el valaki a nyolcadik évfolyamot, annál nagyobb a valószínüsége arra, hogy kimarad a későbbi nyomon követhetőségből - feltételezhetően tehát lemorzsolódtak az iskolából. Mindenesetre a 2013-ban nyolcadik évfolyamot elvégzők 79 százaléka jutott túl 2015-ben sikeresen a tizedik évfolyamon, 6 százalékuk ezt csak a következő évben, 4 százalékuk pedig csak 2017-ben mondhatta el magáról. ${ }^{4}$

3 Előfordulhat, hogy a bázisévként kijelölt 2011. évi felmérésben részt vevők között már volt olyan, aki évismétlőként vett részt a kutatásban.

4 Teljes bizonyossággal csak a 2018-as kompetenciamérések eredményét figyelembe véve lehetne ezt kijelenteni, hiszen ebben az esetben nem tudjuk, hogy aki szerepel a 2017-es év 10. évfolyamos adatbázisában, az nem ismételt-e évet ebben az évfolyamban. 
3. táblázat: Elörehaladás nyolcadik és tizedik évfolyam között, \% $(N=94047)$

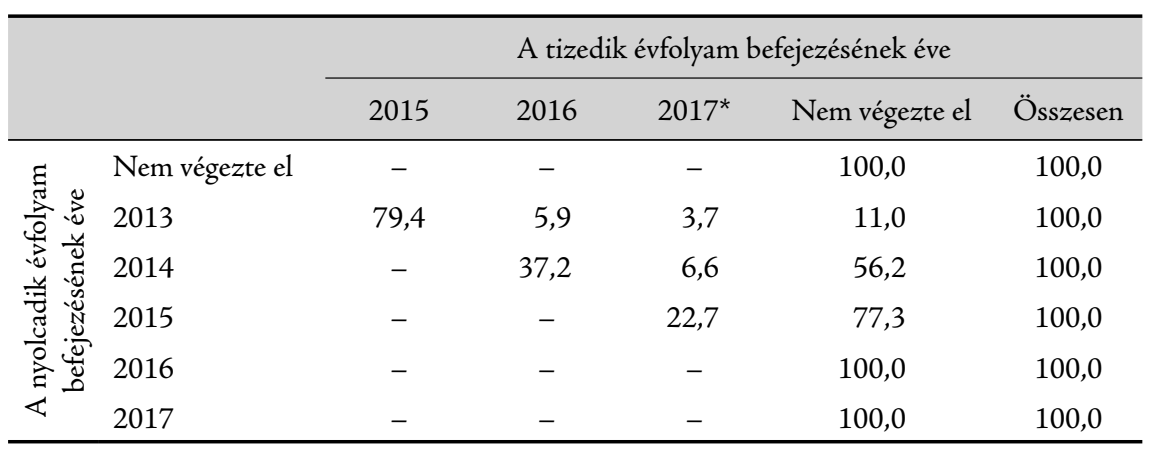

*A rovatban a 2017-es évben 10. évfolyamon regisztrált tanulók aránya, nem a 10. évfolyamot elvégzett tanulók aránya található.

\section{Lemorzsolódás}

A panel alkalmas arra, hogy a tanulói lemorzsolódásra is becsléseket fogalmazzunk meg. Lemorzsolódó tanulóknak azokat tekintem, akik a 2011. évi hatodik évfolyamos mérésben részt vettek, ám a 2013-2017. években a nyolcadikos, illetve a 2015-2017. években a tizedikes mérésekben már nem szerepeltek. A lemorzsolódás ilyenképp való értelmezésekor bizonyos korlátokat is figyelembe kell venni. Egyrészt a tanulmányi út megszakadása (azaz, ha egy tanuló részt vesz az 6. évfolyamos OKM-en, de a 8. évfolyamoson már nem; vagy részt vesz a 6. és a 8. évfolyamos OKM-en, de a 10. évfolyamoson már nem) nem jelenti automatikusan azt, hogy a tanuló végleg lemorzsolódott, hiszen akár HÍD-program, akár felnőttoktatás vagy felnőttképzés keretében befejezheti az általános iskolát, illetve valamilyen szakvégzettséget szerezhet. Emiatt - figyelembe véve az életkori korlátokat is - a lemorzsolódás általunk használt mutatója eltér az iskolai pályafutás sikertelenségét mérő más indikátoroktól (pl. végzettség nélküli iskolaelhagyók indikátora, vagy a nem dolgozó, nem tanuló fiatalok indikátora). Másrészt azért sem feleltethető meg az operacionalizált mutató tökéletesen a lemorzsolódás definíciójának, mert egy tanuló külföldre költözése, haláleset, vagy súlyos testi/értelmi fogyatékosság elszenvedése (vagy a tanuló átminősítése) miatt is kieshet a 8. vagy 10. évfolyamos kompetenciamérésből. Harmadrészt az adatbázis a 10. évfolyamot tartalmazza utolsó panelhullámként, és nyilvánvaló, hogy akár a szakmaszerzésig, akár az érettségiig van elvi lehetőség a további lemorzsolódásra. Utóbbi szempont torzító hatását azonban csökkenti, hogy a középfokú lemorzsolódás zöme a 9. évfolyamban következik be (Fehérvári 2015; Szemerszki 2016).

Ugyanakkor arra is tekintettel kell lenni, hogy a vizsgált időszakba középfokon csupán két évismétlés fér bele, emiatt pedig túlzás lenne azt állítani, hogy az összes olyan tanuló, akinek a 2015-2017, években nincs tizedik évfolyamos kompetenciamérési részvétele (de van nyolcadik évfolyamos), lemorzsolódó tanuló lenne. E csoport esetében talán helyesebb, ha a lemorzsolódás kapcsán magas rizikófaktorú tanulókként hivatkozunk rájuk. ${ }^{5}$

5 Adná magát a „lemorzsolódással veszélyeztetett” kifejezés, de ez a terminus technicus már foglalt és más tartalmat jelöl. A nemzeti köznevelésről szóló 2011. évi CXC. törvény szerint azok a tanulók sorolhatók e kategória alá, akiknek a tanulmányi átlageredménye egy adott tanévben közepes teljesítmény alatti, illetve a megelőző tanévi átlageredményhez képest legalább 1,1 százalékos mértékű romlást mutat. 
Összességében a 2011. évben hatodik évfolyamos kompetenciamérésben részt vevő tanulók 73 százaléka haladt tovább évismétlés nélkül és végezte el 2015-ben a 10. évfolyamot. A tanulók további 10 százaléka vagy az általános iskolában, vagy középfokon valamikor évet ismételt (akár többször is), de legalább 2017-ben van regisztrált 10. évfolyamos mérési bejegyzése. 11 százaléknyian vannak azok a tanulók, akik a lemorzsolódás kapcsán magas rizikófaktorú csoportba tartoznak, és 5 százaléknyian azok, akiket lemorzsolódott tanulónak tekinthetünk.

Hatodik évfolyamon a (később) folyamatosan továbbhaladó tanulók 95 százaléka járt általános iskolába, 5 százaléka pedig 8 évfolyamos gimnáziumba (4. táblázat). Az évismétlő, a lemorzsolódás kapcsán magas rizikófaktorú és a lemorzsolódott tanulók között jóval kisebb (1\% körüli) a szerkezetváltó gimnáziumban tanulók hányada. A nyolcadikos kompetenciamérés alkalmával a folyamatosan haladók közel hét százaléka 6 évfolyamos gimnáziumban tanult. Az évismétlő, illetve a lemorzsolódással kapcsolatban magas rizikófaktorú csoport tanulói szinte kizárólag általános iskolában tanultak. A tizedik évfolyamban nincs lehetőségünk arra, hogy a lemorzsolódott tanulók, illetve a lemorzsolódással kapcsolatban magas rizikófaktorú tanulók iskolatípusát vizsgálni tudjuk: az előbbi csoport nem jutott el a középfokú iskoláig; az utóbbiakról pedig - bár valószínüleg elkezdték tanulmányaikat - az adatbázisokból nem derül ki, milyen típusú iskolába iratkoztak be. Annyi azonban látható, hogy a folyamatosan továbbhaladó tanulók körében a leggyakoribb iskolatípus középfokon a gimnázium: 47,6 százalékuk jár hagyományos vagy szerkezetváltó gimnáziumba. További 36 százalékuk szakgimnazista, 16 százalékuk pedig szakközépiskolás. Azok, akik általános iskolai vagy középiskolai tanulmányaik alatt évet ismételtek (de még nem számítanak a lemorzsolódás kapcsán magas rizikófaktorú csoportnak) az érettségit nem nyújtó szakképzés iskoláiba kerültek a legnagyobb arányban (45,2\%). Szakgimnáziumba a folyamatosan továbbhaladók 36,7 százaléka, gimnáziumba pedig 17,1 százalékuk járt.

Bináris logisztikus regresszióanalízis segítségével megvizsgáltam, mely tényezők járulnak hozzá ahhoz, hogy egy tanuló lemorzsolódóvá váljék. A vizsgálatba bevont mutatók a hatodik évfolyamos kompetenciamérés adatait tükrözik (ahol lehetett - például a szülők iskolázottságánál - a visszapótló eljárást alkalmaztam). Három tényezőcsoportot vontam be a magyarázóváltozóim közé: intézményi jellemzőket (iskolatípus, fenntartó, iskola településtípusa, iskola járása milyen fejlettségi kategóriába tartozik ${ }^{6}$, iskolaméret ${ }^{7}$ ), teljesítményjellemzőket (matematikai és szövegértési kompetenciaterületeken milyen képességszintet értek el a tanulók), valamint személyes háttérjellemzőket (nem; születési év; lakóhely településtípusa; a lakóhely járása milyen fejlettségi kategóriába tartozik; szülők iskolázottsága; a tanuló sajátos nevelési igényü-e; a tanuló küzd-e beilleszkedési, tanulási vagy magatartászavarral; a tanuló halmozottan hátrányos helyzetü-e; a tanuló

\footnotetext{
6 A Kormány 106/2015. (IV.23.) Korm. rendelete a kedvezményezett járások besorolásáról szóló 290/2014. (XI. 26.) Korm. rendelet módosításáról szerint a járásokat négy csoportba sorolják a járás összesített, ún. Komplex-mutató értéke alapján: komplex programmal fejlesztendő járás, fejlesztendő járás, kedvezményezett járás, illetve nem kedvezményezett járás.

7 Az iskolaméret az adott évfolyamban a jelentésre jogosult tanulólétszám alapján került kiszámításra.
} 
4. táblázat: Tanulói továbbhaladás évfolyamok és intézménytípus szerint, $\%(N=94047,89323$, $78569)$

\begin{tabular}{|c|c|c|c|c|c|c|}
\hline & & 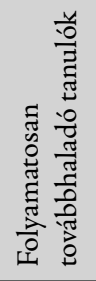 & 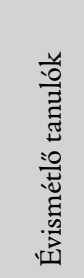 & 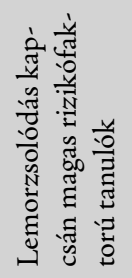 & 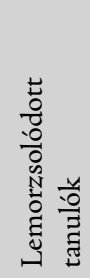 & $\begin{array}{l}\tilde{U} \\
\tilde{U} \\
\mathbb{N} \\
\tilde{n} \\
: 0\end{array}$ \\
\hline \multirow{3}{*}{ 6. évfolyam } & általános iskola & 95,0 & 98,6 & 99,0 & 98,8 & 96,0 \\
\hline & 8 évfolyamos gimnázium & 5,0 & 1,4 & 1,0 & 1,2 & 4,0 \\
\hline & összesen & 100,0 & 100,0 & 100,0 & 100,0 & 100,0 \\
\hline \multirow{4}{*}{ 8. évfolyam } & általános iskola & 88,3 & 96,7 & 98,1 & 0,1 & 90,4 \\
\hline & 8 évfolyamos gimnázium & 5,0 & 1,2 & 0,9 & - & 4,1 \\
\hline & 6 évfolyamos gimnázium & 6,8 & 2,2 & 1,0 & - & 5,6 \\
\hline & összesen & 100,0 & 100,0 & 100,0 & 100,0 & 100,0 \\
\hline \multirow{7}{*}{ 10. évfolyam } & 8 évfolyamos gimnázium & 4,3 & 0,4 & - & - & 3,2 \\
\hline & 6 évfolyamos gimnázium & 6,1 & 1,2 & - & - & 4,6 \\
\hline & 4 évfolyamos gimnázium & 37,2 & 15,5 & - & - & 28,8 \\
\hline & szakgimnázium & 36,4 & 36,7 & - & - & 30,4 \\
\hline & szakközépiskola & 16,0 & 45,2 & - & - & 16,4 \\
\hline & szakiskola & 0,1 & 0,9 & - & - & 0,2 \\
\hline & összesen & 100,0 & 100,0 & 100,0 & 100,0 & 100,0 \\
\hline
\end{tabular}

lakóhelye megegyezik-e az iskola településével; a tanuló iskolájában mekkora arányban tanulnak roma származású tanulók $\left.{ }^{8}\right)$.

A modell a függő változó (lemorzsolódó-e egy tanulóp) varianciájának 34 százalékát magyarázza meg (5. táblázat). Az intézményi jellemzők közül két tényező mutatott érdemi befolyást a lemorzsolódásra: az iskola fenntartója, illetve a feladatellátási hely településtípusa. Az egyházi és önkormányzati ${ }^{10}$ iskolák érdemben nem különböznek egymástól, ugyanakkor az egyéb (főként alapítványi) fenntartású iskolákba járók körében közel négyszeres a lemorzsolódás valószínűsége. Nyilván nem arról van szó, hogy ezek az iskolák „elriasztják” a tanulókat, hanem inkább arról, hogy ebben az intézményi körben jóval nagyobb azon iskolák aránya, amelyek kifejezetten valamilyen tanulási, magatartási nehézséggel küzdő tanulókkal foglalkoznak. A budapesti iskolák tanulói körében

8 A kompetenciamérés során a telephelyi kérdőívben a telephelyek vezetői nyilatkoznak arról, hogy iskolájukban becslésük szerint mekkora a roma származású tanulók aránya. Ez a becslés azonban nemcsak az iskola egyik jellemzője, hanem a tanulói adatok mellé rendelve lényegében egy valószínűségi mutató arra nézve, hogy a vizsgált tanuló roma származású-e vagy sem.

9 A modellben arra törekedtem, hogy viszonylag „tiszta” hatásokat tárjak fel. Emiatt a függő dichotóm változó 1-es értéke a lemorzsolódó tanulókat jelöli ki, a 0 érték viszont nem a többi, nem lemorzsolódó tanulóra, hanem a folyamatosan továbbhaladó tanulói körre vonatkozik.

10 2011-es adatokról van szó, azóta az önkormányzati iskolák java része tankerületi fenntartás alá került. 


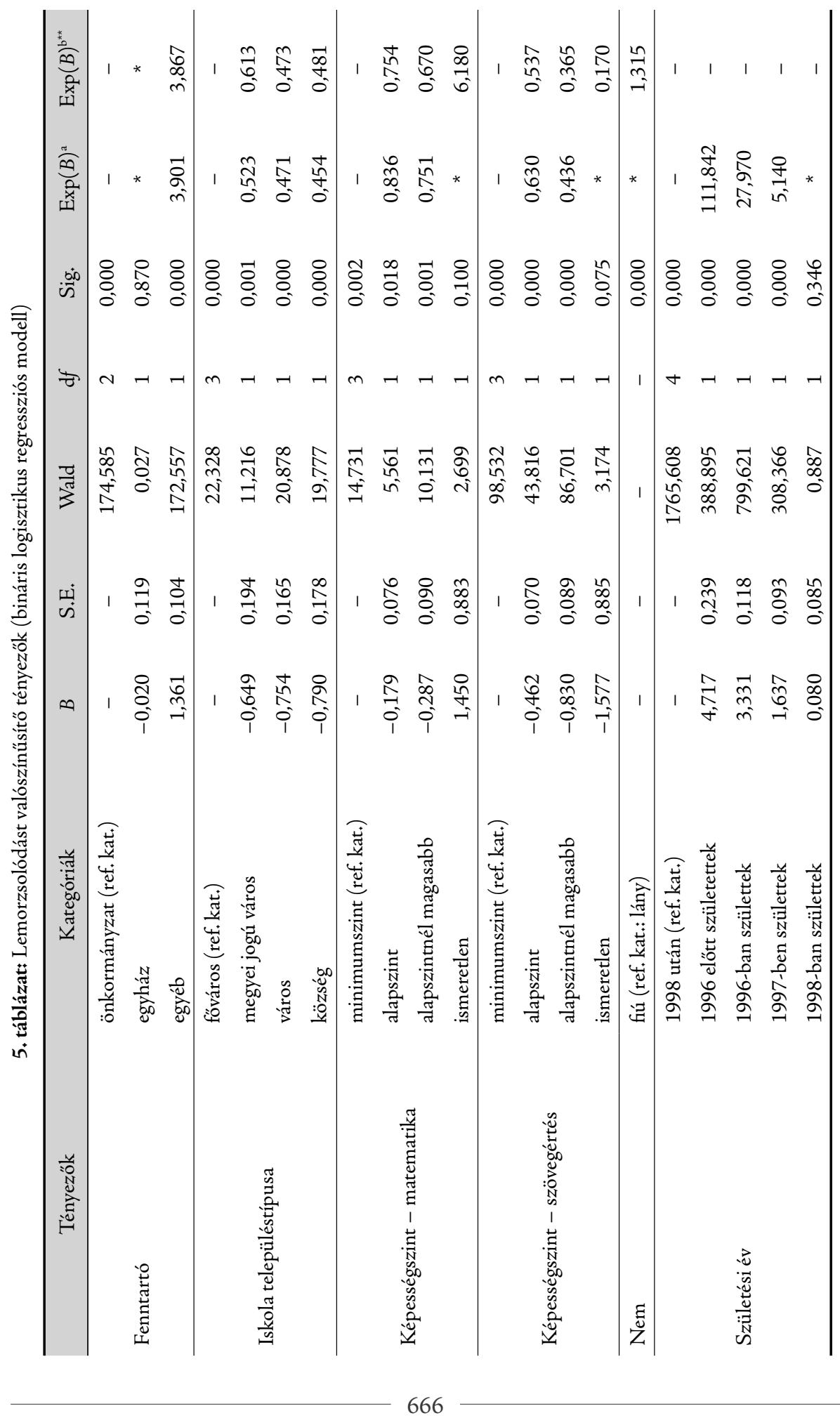




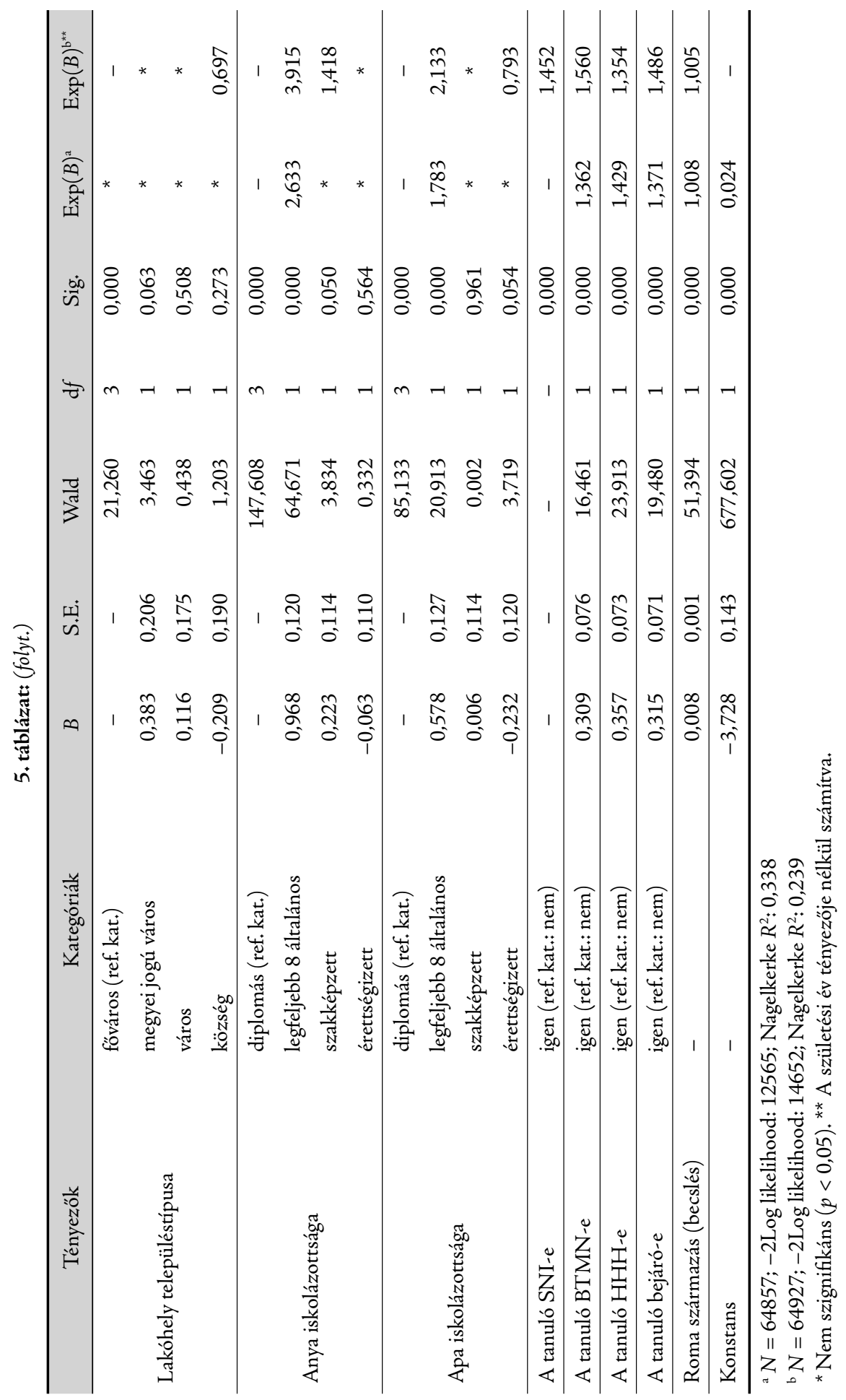


nagyságrendileg kétszer nagyobb a lemorzsolódás valószínűsége, mint a vidéki városok, községek iskoláiban (melyek között lényegi eltérés nem látható). A teljesítménymutatók szintén szignifikánsak a modellben, és jellemző módon főleg a szövegértési kompetenciák mutatnak nagyobb differenciát. E kompetenciaterületen a minimumszintet el nem érő tanulókhoz $z^{11}$ képest az alapszintet elérő tanulók ${ }^{12}$ valószínűségi együtthatója 0,63 , az ennél magasabb szintet elérőké 0,44, azaz minél gyengébb szövegértési kompetenciákkal rendelkezik valaki, annál nagyobb az esélye a lemorzsolódásra. A személyes jellemzők közül a legmarkánsabb hatást a tanulók életkora mutatja. A vizsgált évfolyamon a jellemző születési év az 1998, illetve 1999, hozzájuk képest minél korábban született valaki, annál nagyobb az esélye arra, hogy nem végzi el az iskolát. Markáns befolyásoló tényező még a szülők iskolai végzettsége (föleg az anyáé): ha nincs meg a szülőnek az általános iskolai 8 osztályos bizonyítványa, két-két és félszeres lesz az esély arra, hogy a gyereke is kihull az iskolából. A tanulók lakóhelyének településtípusa is érdemi hatást mutat: a megyeszékhelyeken, megyei jogú városokban tanulók körében a községi tanulókhoz képest jóval magasabb a lemorzsolódás. Növeli a lemorzsolódás valószínűségét, ha a vizsgált tanuló fiú; ha beilleszkedési, magatartási vagy tanulási nehézségekkel küzd; ha halmozottan hátrányos helyzetü; vagy ha bejáró (azaz a lakóhelye és az iskola települése eltér egymástól). A roma származás szintén növeli a lemorzsolódás esélyét (ha az iskolába csak roma tanulók járnak, a lemorzsolódás esélyhányadosa közel kétszeres).

A fenti magyarázóváltozók közül a túlkorosságot jelző születési év mutatója túlságosan is hangsúlyos, így érdemesnek tartottam a modellt e változó nélkül is megvizsgálni. A megmagyarázott hányad valamelyest lecsökken (24\%), de a befolyásoló tényezők szerkezete alig változik. Új szempontként csak a tanuló sajátos nevelési igényét lehet megállapítani: ha valaki SNI minősítést kapott, az jelentősen megnöveli a lemorzsolódás esélyét. Az esélyhányadosok főleg a tanulók teljesítményei, illetve személyes háttérjellemzői esetében változnak - jellemzően nőnek, ami rámutat arra, hogy a túlkorosság e jellemzőkkel függ össze erősen.

Ugyanezzel a módszerrel vizsgáltam meg azt is, vajon a fenti magyarázóváltozók közül mi mutat érdemi befolyást arra, hogy egy tanuló beletartozik-e a lemorzsolódás kapcsán magas rizikófaktorú csoportba vagy sem (szintén a folyamatosan továbbhaladó tanulókhoz képest) (6. táblázat). A rizikócsoportba tartozásnak az önkormányzati fenntartású iskolákkal összevetve az egyházi iskolákban kisebb, az egyéb fenntartású iskolákban nagyobb a valószínüsége. A feladatellátási hely településtípusa is csak a fơváros és a kisebb vidéki városok relációjában érdekes (Budapesten nagyobb a valószínüsége a rizikócsoportba tartozásnak, mint a kisvárosokban). Új szempontként viszont meg kell említeni az iskolaméretet: minél kisebb tanulólétszámú iskolába jár egy tanuló, annál valószínűbb, hogy nagyobb az esélye a rizikócsoportba tartozásra. A tanulói teljesítmény, a túlkorosság, a lakóhely, a bejárás ténye, illetve a személyes háttérjellemzők (SNI, BTM, $\mathrm{HHH}$, roma származás) szintén markáns befolyásoló tényezők. A lemorzsolódókhoz képest lényegi különbség, hogy a rizikócsoportba nagyobb valószínüséggel tartoznak azok, akiknek szülei legfeljebb szakmunkás bizonyítvánnyal rendelkeznek, illetve a nem szerepe nem releváns ebben a kérdésben.

11 20/2012. (VIII. 31.) EMMI rendelet alapján a 6. évfolyamon a 2. képességszintet el nem érő tanulókról van szó.

12 Az alapszint a 6. évfolyamon a 3. képességszintet jelenti. 


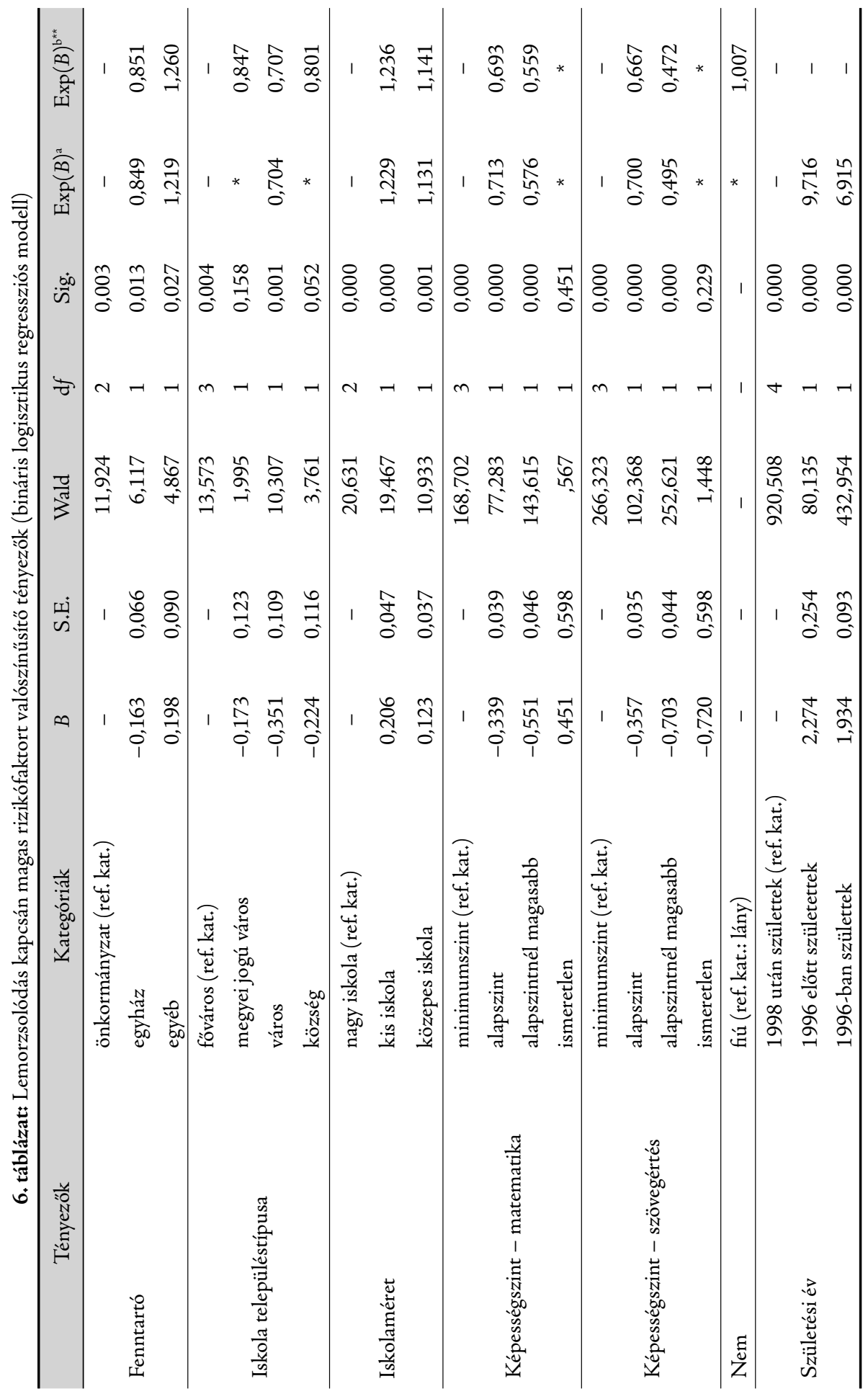




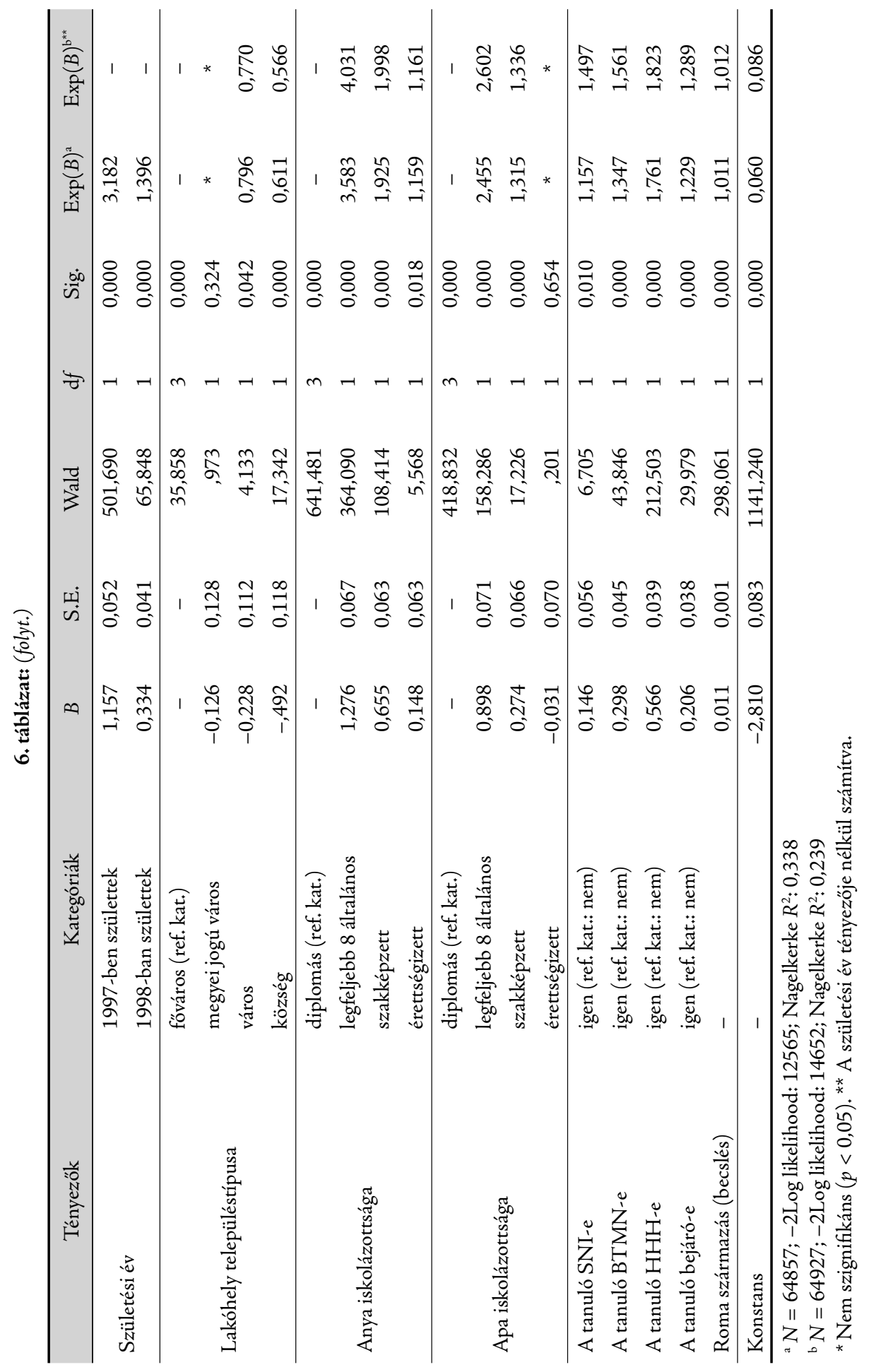




\section{Társadalmi háttér és tanulói teljesítmény}

A fenti logisztikus regressziós modellek is rámutattak arra, hogy a tanulók társadalmi háttere és tanulási útja, illetve végső soron tanulói teljesítménye között szoros összefüggés van. Az OKM a társadalmi hátteret egy összetett mutatóban, az ún. családiháttérindexben (CSHI) igyekszik megragadni. Ha ezt a mutatót és egy teljesítményindikátort (például a matematika kompetenciaterületen elért pontszámokat) egy Descartes-féle koordinátarendszerben ábrázoljuk, ahol a függőleges tengely a CSHI-t, a vízszintes tengely pedig a tanulói teljesítményt jelöli, az egyes tanulókat pontonként ábrázolva az 1. ábrán látható felhődiagrammot kapjuk. ${ }^{13}$

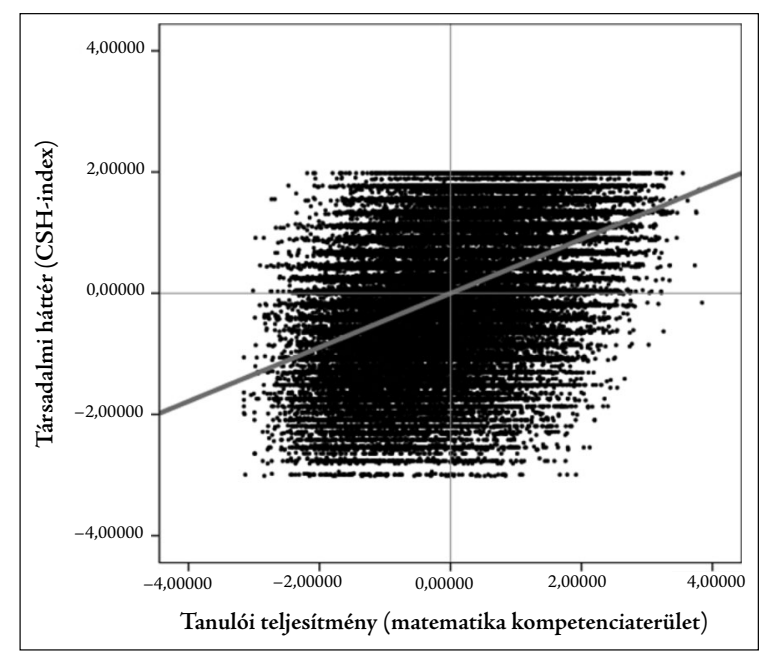

1. ábra: Társadalmi háttér és tanulói teljesítmény $(N=81595)$

A diagrammon feltüntettük a pontokra húzott lineáris regressziós egyenest, mely jól szemlélteti, hogy minél kedvezőtlenebb egy tanuló társadalmi háttere, annál alacsonyabb teljesítményt valószínűsíthetünk, és fordítva, minél kedvezőbb egy tanuló társadalmi háttere, annál magasabb teljesítmény lesz jellemző. Ez az összefüggés azonban korántsem érvényes minden tanuló esetében. A függvény szerint a koordinátarendszer jobb felső sarkában azokat a tanulókat találjuk, akiknek kedvező háttere jó teljesítménnyel párosul (e csoport tagjait hívhatjuk kedvezményezett tanulóknak), bal alsó sarkában pedig azokat, akiknek kedvezőtlen háttere gyenge teljesítménnyel jár együtt (kárvallott tanulók). Mindkét tengely átlaga (nulla pontja) körül azok a tanulók láthatók, akik átlagosnak (tipikusnak) nevezhetők. A koordinátarendszer bal felső sarkában az a tanulói csoport jelenik meg, melyek kedvező társadalmi hátterük ellenére gyengén teljesítenek (alulteljesítők), jobb alsó sarkában pedig azok, akik kedvezőtlen hátterük ellenére jó teljesítménnyel rendelkeznek (reziliensek). A tipikus tanulókat az átlagtól való egy szórásnyi távolságra határoltam le, illetve az így kapott „körre” pedig elforgatott hiperbolákat illesztettem, melyek segítségével kialakítottam a fenti négy tanulócsoportot (2.ábra). A lehatárolás e módját az indokolja, hogy a hagyományosan alkalmazott eljárások durva kategorizáláson

13 Az egységes skála miatt mindkét dimenzióban a nulla átlagú, 1 szórású standardizált értékek szerepelnek. 
alapulnak, és kevésbé veszik figyelembe a relatív eltéréseket. Például, a reziliens tanulók OECD-meghatározásánál bevett, hogy a társadalmi háttér szerinti alsó, teljesítmény szerinti felső negyedbe tartozókat tekintik kiválasztási szempontnak (OECD 2010, 2013, 2016), de léteznek más tipizálási eljárások is (Csüllög-Lannert-Zempléni 2015; Tóth et al. 2016; Agasisti et al. 2018; Hörich 2018). Ebben az esetben azonban nem számítanak azok, akik nagyon kedvezőtlen helyzetből indulva az átlagnál kicsit jobb teljesítményre képesek - holott e tanulók többletteljesítménye azonos vagy nagyobb, mint azoké, akik kedvezőtlen (de nem nagyon kedvezőtlen) helyzetből az előző csoporthoz képest csak kicsit jobb teljesítményt nyújtanak.

A teljes, 2011-ben 6. évfolyamos OKM-ben megjelenő tanulói populáció mintegy 87 százalékát $(N=81595)$ lehetséges ezzel a módszerrel valamelyik csoportba besorolni. Tipikus tanulónak e „minta” 41,6 százaléka, kedvezményezett tanulónak 16,5 százaléka, alulteljesítő tanulónak 4,5 százaléka, kárvallott tanulónak 16,1 százaléka, reziliens tanulónak pedig 4 százaléka számít. További 17,3 százaléknyi tanuló az egyik szempont szerint extrém, a másik szempont szerint átlagos értéket vett föl, de e tanulói kategóriával e tanulmányban nem foglalkozom.

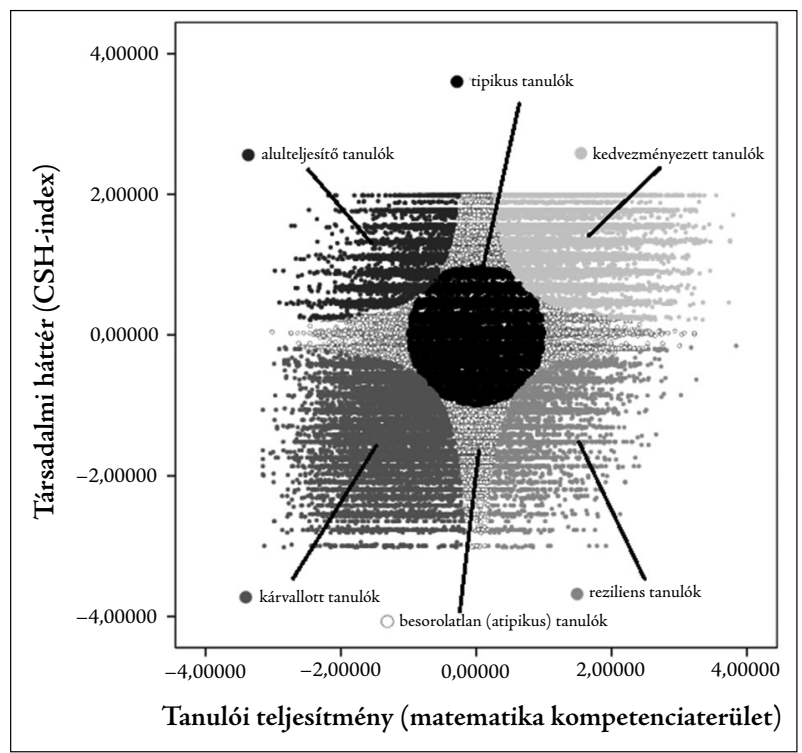

2. ábra: Tanulói csoportok a társadalmi háttér és a tanulói teljesítmény függvényében $(N=81595)$

A tanulói utat tekintve - nem váratlanul - a kedvezményezett tanulók vannak a legkedvezőbb helyzetben (7. táblázat). E csoport tagjainak 94,5 százaléka folyamatosan halad tanulmányi útján. A tipikus (átlagos) tanulók 83,7 százalékára jellemző a folyamatos továbbhaladás, 10,6 százalékuk évismétlő, 4,6 százaléka a lemorzsolódás kapcsán magas rizikófaktorral jellemezhető, 1 százaléka pedig lemorzsolódó. A reziliensek körében magas, 16,4 százalék a rizikócsoport részaránya, és az átlagnál közel tíz százalékponttal alacsonyabb a folyamatosan továbbhaladók hányada. A kárvallott tanulók körében a legmagasabb a rizikócsoport (27,8\%) és a lemorzsolódók (6,4\%) aránya, egyúttal jellemző, hogy e csoport tagjai közül csak alig minden második tanuló halad folyamatosan tanulói útján. 


\begin{tabular}{|c|c|c|c|c|c|}
\hline & 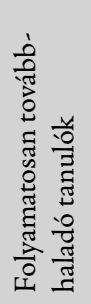 & 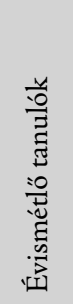 & 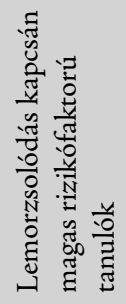 & 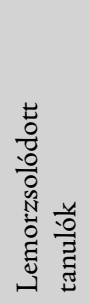 & $\begin{array}{l}\text { एँ } \\
\tilde{W} \\
\mathbb{N} \\
0 \\
0\end{array}$ \\
\hline Átlagos (tipikus) tanulók & 83,7 & 10,6 & 4,6 & 1,0 & 100,0 \\
\hline Kedvezményezett tanulók & 94,5 & 3,0 & 1,7 & 0,9 & 100,0 \\
\hline Alulteljesítő tanulók & 80,8 & 12,1 & 5,4 & 1,8 & 100,0 \\
\hline Kárvallott tanulók & 49,6 & 16,1 & 27,8 & 6,4 & 100,0 \\
\hline Reziliens tanulók & 68,8 & 12,3 & 16,4 & 2,5 & 100,0 \\
\hline Összes csoportosított tanuló & 78,4 & 10,5 & 9,0 & 2,1 & 100,0 \\
\hline
\end{tabular}

A kedvezményezett tanulók közül négyszer annyian jártak hatodik évfolyamban 8 évfolyamos gimnáziumba (12,8\%), mint a tipikus (átlagos) tanulók $(3,1 \%)$ (8. táblázat). Utóbbi csoporthoz képest a szerkezetváltó gimnázium még az alulteljesítő tanulók körében is gyakoribb (4,1\%). A kárvallottak, illetve a reziliens tanulók körében elvétve találunk olyan tanulót, aki 8 évfolyamos gimnáziumban tanult volna. A következő mérési ponton, a 8 évfolyamon a megfigyelt széttartás még jellemzőbb: a kedvezményezett tanulók további 18 százaléka járt 6 évfolyamos gimnáziumba, miközben a tipikus (átlagos) tanulók körében ez az arány mindössze 3,7\%. Az alulteljesítők körében 5,5 százaléknyian kerültek ebbe az iskolatípusba, miközben a kárvallott és reziliens tanulók körében továbbra is nagyon alacsony a részvétel aránya. Középfokon (10. évfolyamban) az átlagos tanulók 32,7 százaléka járt 4 évfolyamos, 5,7 százaléka pedig 6 vagy 8 évfolyamos gimnáziumba. Ugyanakkor e tanulói körben a szakgimnázium a leggyakoribb haladási irány (47,3\%). Mind az alulteljesítő, mind pedig a kedvezményezett tanulók többsége valamilyen gimnáziumi képzésben tanult tovább (előbbiek 49,7, utóbbiak 84,3 százaléka). A reziliens tanulók relatív többsége a szakgimnáziumi képzésbe került $(45,3 \%)$, gimnáziumba csupán 27,7 százalékuk jutott el. Ez arra utal, hogy a társadalmi háttér - a tanulói teljesítményt azonosnak véve - mintegy harmadannyi esélyt biztosít a kedvezőbb középfokú (egyben felsőfok felé orientáló) képzés elérésére. A kárvallott tanulói kör közel kétharmada (62,1\%) szakközépiskolai képzésbe szorult, és tíz százalék alatt marad azok aránya, akik valamilyen gimnáziumban tudtak tovább tanulni. A reziliens és kárvallott tanulói csoportok középfokú továbbhaladási arányainál azt is figyelembe kell venni, hogy a számításba nem került bele a lemorzsolódó, illetve a lemorzsolódás kapcsán magas rizikófaktorú tanulók csoportja, márpedig e két kategória mindkét tanulói körben jelentős (18,9 és 34,2\%). Ha ismernénk, hogy a rizikócsoport tagjai milyen középfokú iskolában tanultak/iratkoztak be, feltehetően a fenti arányoknál még kedvezötlenebb képet, így még nagyobb szelekciós hatást regisztrálhatnánk. 
8. táblázat: Tanulói csoportok évfolyamok és intézménytípusok szerint, \% $(N=67502,66055$, 59854)

\begin{tabular}{|c|c|c|c|c|c|c|c|}
\hline & & 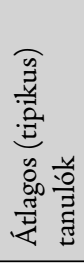 & 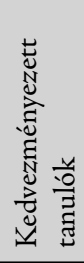 & 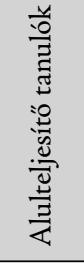 & 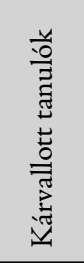 & 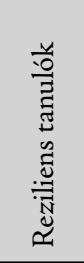 & 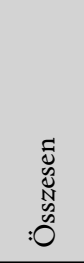 \\
\hline \multirow{3}{*}{ 6. évfolyam } & általános iskola & 96,9 & 87,2 & 95,9 & 99,8 & 99,2 & 95,7 \\
\hline & 8 évfolyamos gimnázium & 3,1 & 12,8 & 4,1 & 0,2 & 0,8 & 4,3 \\
\hline & összesen & 100,0 & 100,0 & 100,0 & 100,0 & 100,0 & 100,0 \\
\hline \multirow{4}{*}{ 8. évfolyam } & általános iskola & 93,3 & 69,3 & 90,6 & 99,5 & 97,4 & 89,9 \\
\hline & 8 évfolyamos gimnázium & 3,0 & 12,6 & 4,0 & 0,2 & 0,8 & 4,3 \\
\hline & 6 évfolyamos gimnázium & 3,7 & 18,1 & 5,5 & 0,4 & 1,8 & 5,8 \\
\hline & összesen & 100,0 & 100,0 & 100,0 & 100,0 & 100,0 & 100,0 \\
\hline \multirow{7}{*}{ 10. évfolyam } & 8 évfolyamos gimnázium & 2,5 & 11,0 & 3,3 & 0,1 & 0,6 & 3,8 \\
\hline & 6 évfolyamos gimnázium & 3,2 & 16,7 & 4,8 & 0,4 & 1,5 & 5,6 \\
\hline & 4 évfolyamos gimnázium & 32,7 & 56,6 & 41,6 & 8,3 & 25,6 & 34,9 \\
\hline & szakgimnázium & 47,3 & 15,2 & 36,9 & 28,7 & 45,3 & 36,8 \\
\hline & szakközépiskola & 14,2 & 0,6 & 13,3 & 62,1 & 26,8 & 18,7 \\
\hline & szakiskola & 0,1 & - & 0,1 & 0,3 & 0,2 & 0,1 \\
\hline & összesen & 100,0 & 100,0 & 100,0 & 100,0 & 100,0 & 100,0 \\
\hline
\end{tabular}

A később ismertetett magyarázó modellekbe nehezen illeszthető be részletes területi szempont, ám mivel jelentős különbségek figyelhetők meg az egyes tanulói csoportok arányait tekintve, érdemes kitérni ezekre a differenciákra. Járási bontásban, térképen ábrázolva a tanulói csoportok arányait, látható, hogy a tipikus (átlagos) tanulók alulreprezentáltak az ország keleti és északkeleti határmenti övezetében; Békés, Hajdú-Bihar és Jász-Nagykun-Szolnok megye határvidékén; a délnyugat-magyarországi határmenti járásokban, valamint a fövárosban és agglomerációjában (3. ábra). Utóbbi térségben ezt az okozza, hogy a vártnál jóval magasabb arányban találjuk a kedvezményezett tanulókat (4. ábra). E tanulócsoport tagjainak átlagost meghaladó arányát még néhány nagyvárosban (például Győr, Veszprém, Székesfehérvár, Pécs, Szeged, Debrecen, Eger) mérhetjük. A kárvallott tanulók arányai járásonként - a fövárost és agglomerációját, illetve az említett városokat leszámítva - közel a tipikus tanulók arányait bemutató térkép inverze (5. ábra). A reziliens tanulókat magasabb arányban néhány északkelet- és délnyugatmagyarországi járásban (például a Csengeri, Mátészalkai, Nyírbátori, Vásárosnaményi, Edelényi, Encsi, Barcsi, Szigetvári és Sellyei járásban) találjuk (6. ábra). ${ }^{14}$ A megfigyelt területi különbségeket csak részben magyarázzák az ország általános gazdasági-társadalmi

14 E csoport térbeli differenciáltságát egyelőre csak rögzítem, lehetséges okait egy későbbi elemzésben vizsgálom majd meg. 


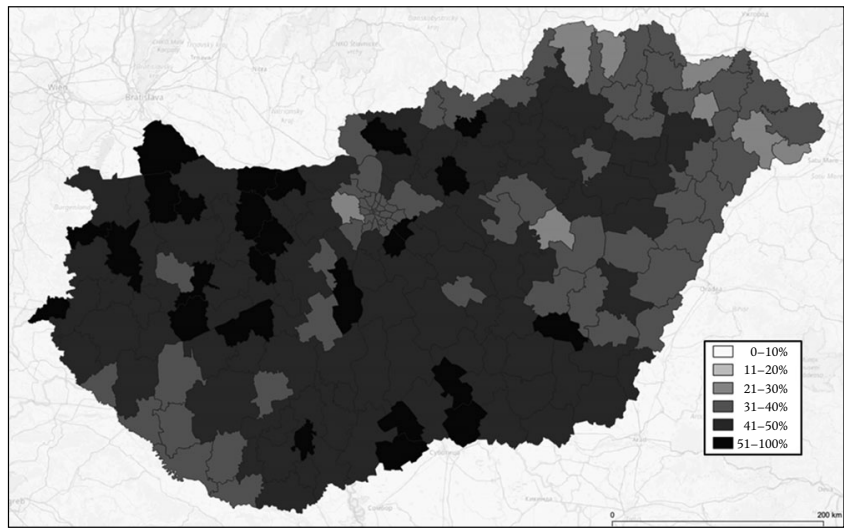

3. ábra: Tipikus (átlagos) tanulók aránya járásonként, \%

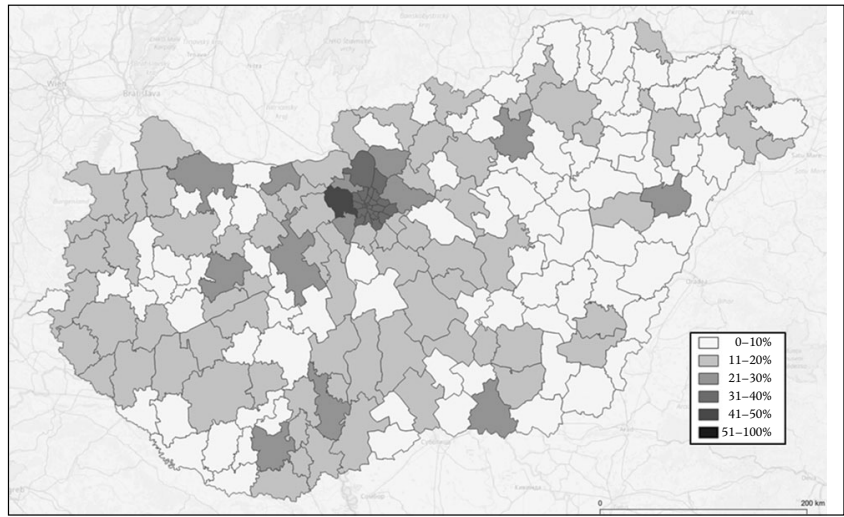

4. ábra: Kedvezményezett tanulók aránya járásonként, \%

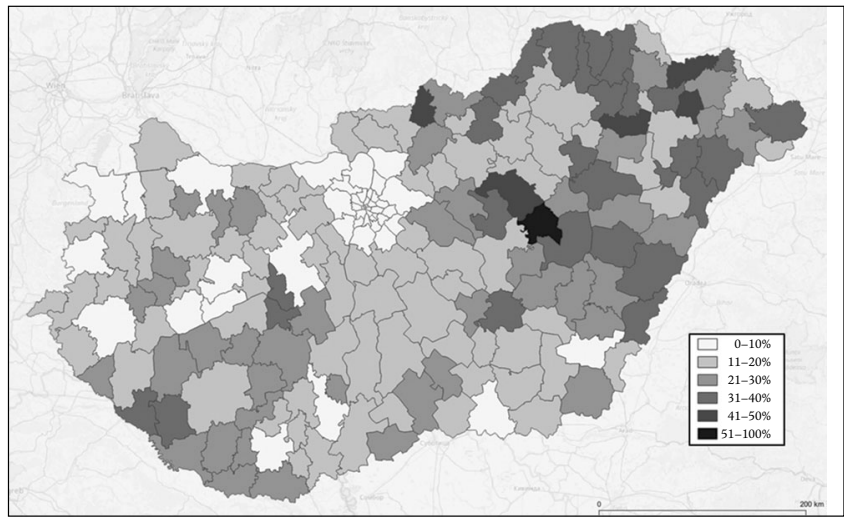

5. ábra: Kárvallott tanulók aránya járásonként, \%

különbségei. Bár oksági kapcsolat természetesen nem tételezhető fel két tényező területi eloszlásából, érdemes összehasonlítani a 2011. évi népszámlálás cigány (roma) nemzeti- 


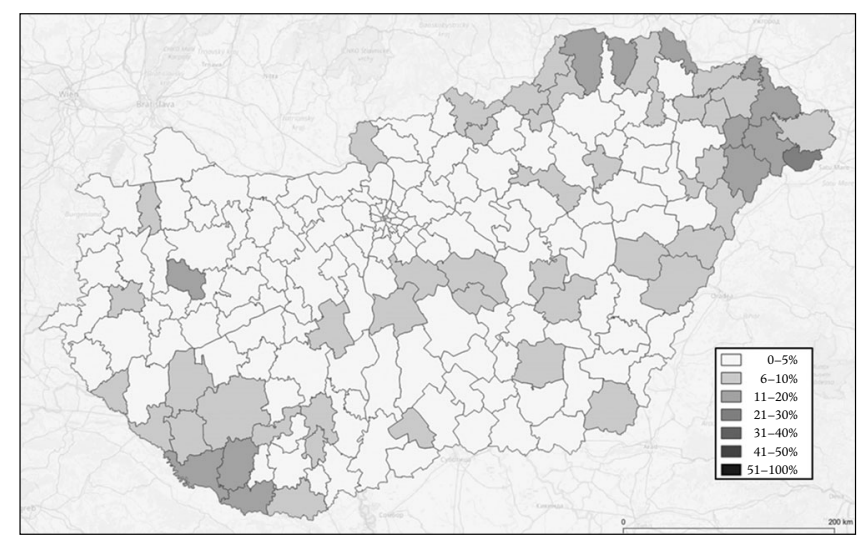

6. ábraः Reziliens tanulók aránya járásonként, \%

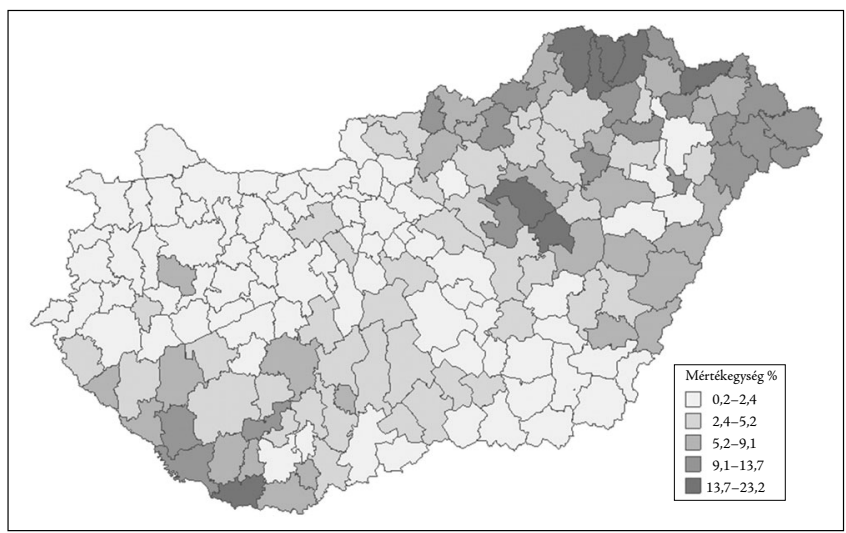

7. ábra: Roma (cigány) nemzetiségűek aránya, \%. Forrás: KSH, 2011. évi népszámlálás (https://map.ksh.hu/timea/)

séghez tartozó arányainak járási összegzését (7. ábra), illetve a kárvallott tanulók arányait megjelenítő térképet - a két térkép nagyon hasonló mintázatot mutat.

Bináris logisztikus regresszióanalízis segítségével megvizsgáltam, milyen intézményi, tanulói teljesítmény, valamint személyes háttérjellemzők befolyásolják a tipikus (átlagos) tanulókhoz képest az egyes tanulói csoporttagságot (9. táblázat). A modell eredményei szerint a kedvezményezett és alulteljesítő tanulók nagyobb valószínűséggel tanultak egyházi és egyéb fenntartású, nagy tanulólétszámú intézményekben; illetve kisebb eséllyel a vidéki, közepes vagy kis létszámú iskolákban. A kárvallott és reziliens tanulók esetében ez lényegében fordítva alakul. A jobb teljesítményen alapuló kedvezményezett és reziliens csoportokban a fuúk bekerülési esélye magasabb. A túlkorosság a kedvezményezettek esetében csoporttagságot csökkentő, a többi csoport esetében csoporttagságot növelő valószínűségi tényező. A személyes jellemzők közül a szociális hátrányokat, a tanulási nehézségeket tükröző és a származást becslő mutatók a kedvezményezett tanulók esetében alacsony, a kárvallott tanulók esetében magas valószínűségi esélyhányadost mutatnak. 
9. táblázat: Tanulói csoportokba sorolást valószínűsítő tényezők (bináris logisztikus regressziós modellek esélyhányadosai)

\begin{tabular}{|c|c|c|c|c|c|c|}
\hline Tényezők & Ref. Kat. & Kat. & 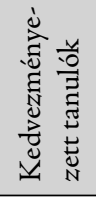 & 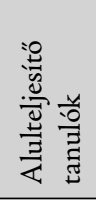 & 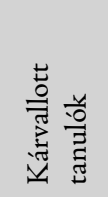 & 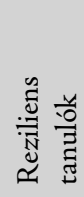 \\
\hline Iskola típusa & $\begin{array}{l}\text { általános } \\
\text { iskola }\end{array}$ & $\begin{array}{l}8 \text { évfolyamos } \\
\text { gimnázium }\end{array}$ & 1,834 & * & 0,102 & 0,447 \\
\hline \multirow{3}{*}{ Iskola fenntartója } & önkormányzati & & - & - & - & - \\
\hline & & egyházi & 1,495 & 1,985 & 0,852 & 0,854 \\
\hline & & egyéb & 2,151 & 3,781 & 1,304 & 0,688 \\
\hline \multirow{4}{*}{ Iskola településtípusa } & fôváros & & - & - & - & - \\
\hline & & $\begin{array}{l}\text { megyei jogú } \\
\text { város }\end{array}$ & 0,514 & 0,562 & 0,978 & 0,989 \\
\hline & & város & 0,399 & 0,616 & 1,857 & 1,006 \\
\hline & & község & 0,311 & 0,617 & 1,926 & 1,306 \\
\hline \multirow{3}{*}{ Iskolaméret } & nagy iskola & & - & - & - & - \\
\hline & & kis iskola & 0,869 & 0,859 & 1,200 & 1,531 \\
\hline & & közepes iskola & 0,874 & 0,884 & 1,137 & 1,229 \\
\hline $\mathrm{Nem}$ & lány & fiú & 1,263 & 0,771 & 0,847 & 1,136 \\
\hline \multirow{5}{*}{ Születési év } & 1998 után & & - & - & - & - \\
\hline & & 1996 előtt & 0,000 & 1,479 & 12,401 & 5,436 \\
\hline & & 1996 & 0,226 & 1,912 & 15,558 & 4,354 \\
\hline & & 1997 & 0,381 & 1,819 & 4,722 & 2,173 \\
\hline & & 1998 & 0,867 & 1,093 & 1,388 & 1,216 \\
\hline \multirow{4}{*}{ Lakóhely besorolása } & nem besorolt & & - & - & - & - \\
\hline & & $\begin{array}{l}\text { kedvezmé- } \\
\text { nyezett }\end{array}$ & 0,891 & 0,665 & 1,372 & 1,868 \\
\hline & & fejlesztendő & 0,421 & 0,505 & 1,389 & 1,764 \\
\hline & & $\begin{array}{l}\text { komplex } \\
\text { programmal } \\
\text { fejlesztendő }\end{array}$ & 0,675 & 0,841 & 1,750 & 1,932 \\
\hline \multirow{4}{*}{$\begin{array}{l}\text { Lakóhely település- } \\
\text { típusa }\end{array}$} & föváros & & - & - & - & * \\
\hline & & $\begin{array}{l}\text { megyei jogú } \\
\text { város }\end{array}$ & 1,086 & 1,092 & 1,625 & - \\
\hline & & város & 0,977 & 0,960 & 1,305 & - \\
\hline & & község & 0,795 & 0,752 & 1,347 & - \\
\hline A tanuló SNI-e & nem & igen & 0,168 & 3,670 & 3,067 & 0,607 \\
\hline
\end{tabular}


9. táblázat: (folyt.)

\begin{tabular}{|c|c|c|c|c|c|c|}
\hline Tényezők & Ref. Kat. & Kat. & 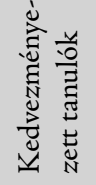 & 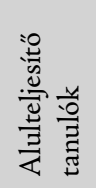 & 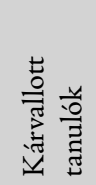 & 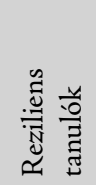 \\
\hline A tanuló BTMN-e & nem & igen & 0,223 & 2,631 & 3,531 & 0,766 \\
\hline A tanuló $\mathrm{HHH}$-e & nem & igen & 0,082 & 0,314 & 15,345 & 12,146 \\
\hline A tanuló bejáró-e & nem & igen & 0,906 & 1,215 & 1,114 & * \\
\hline Romák aránya ${ }^{* *}$ & - & & 0,982 & 0,989 & 1,021 & 1,016 \\
\hline$N$ & & & 44412 & 35981 & 45429 & 35772 \\
\hline -2Log likelihood & & & 46579 & 20991 & 37354 & 17383 \\
\hline Nagelkerke $R^{2}$ & & & $15 \%$ & $9 \%$ & $44 \%$ & $24 \%$ \\
\hline
\end{tabular}

${ }^{*}$ Nem szignifikáns $(p<0,05) .{ }^{* *} \mathrm{~A}$ tanuló iskolájában a roma származásúak aránya

Kérdésként merülhet föl, vajon a kárvallott és reziliens tanulók esetében van-e olyan tényező, ami jelentős mértékben meghatározza azt, hogy vajon a későbbi tanulási útjukon továbbhaladnak-e (folyamatosan vagy egy-két évismétléssel), esetleg lemorzsolódnak, vagy a lemorzsolódás kapcsán magas kockázatúvá válnak-e a tanulók. A bizonytalan továbbhaladó kárvallottak aránya 34,2, a rezilienseké pedig 18,9 százalék. A vizsgálat módszeréül ugyancsak bináris logisztikus regressziós modellt alkalmazva két magyarázóváltozó befolyása erős: a CSHI-é, illetve a roma származásé ${ }^{15}$, ráadásul a két változó interakciója is szignifikánsnak mutatkozott. A 10. táblázatban a folytonos változókat

10, táblázat: Lemorzsolódás vagy az azzal kapcsolatos rizikócsoport aránya a roma származás becsült aránykategóriái, illetve a CSHI kategóriái szerint, kárvallott és reziliens tanulók, \%

$(N=12890,3203)$

\begin{tabular}{|c|c|c|c|c|c|c|c|c|}
\hline \multirow[b]{3}{*}{$\begin{array}{l}\text { Roma szárma- } \\
\text { zással az esély }\end{array}$} & \multicolumn{4}{|c|}{ Kárvallott tanulók } & \multicolumn{4}{|c|}{ Reziliens tanulók } \\
\hline & \multicolumn{4}{|c|}{ CSHI } & \multicolumn{4}{|c|}{ CSHI } \\
\hline & 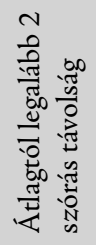 & 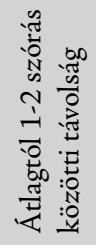 & 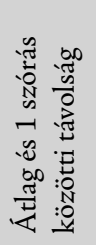 & 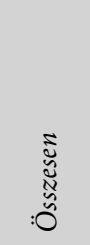 & 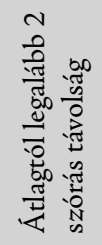 & 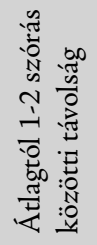 & 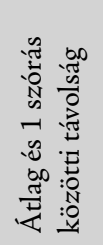 & 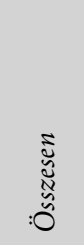 \\
\hline$<20 \%$-nál kisebb & $54,9 \%$ & $32,0 \%$ & $17,9 \%$ & $28,5 \%$ & $42,4 \%$ & $17,5 \%$ & $5,9 \%$ & $12,4 \%$ \\
\hline $21-40 \%$ & $58,1 \%$ & $35,5 \%$ & $20,2 \%$ & $35,3 \%$ & $48,3 \%$ & $24,9 \%$ & $8,2 \%$ & $21,6 \%$ \\
\hline $41-60 \%$ & $62,3 \%$ & $41,9 \%$ & $24,9 \%$ & $44,7 \%$ & $48,4 \%$ & $29,7 \%$ & $8,5 \%$ & $28,9 \%$ \\
\hline $61-80 \%$ & $56,9 \%$ & $40,9 \%$ & $23,7 \%$ & $43,5 \%$ & $42,0 \%$ & $28,7 \%$ & $0,0 \%$ & $30,2 \%$ \\
\hline $81-100 \%$ & $60,5 \%$ & $49,4 \%$ & $32,5 \%$ & $52,1 \%$ & $51,4 \%$ & $43,1 \%$ & $42,9 \%$ & $46,4 \%$ \\
\hline Összesen & $58,0 \%$ & $35,6 \%$ & $19,2 \%$ & $34,2 \%$ & $46,4 \%$ & $23,2 \%$ & $6,5 \%$ & $19,0 \%$ \\
\hline
\end{tabular}

15 A CSHI ebben az esetben a két csoport belső - végeredményben státusz szerinti - heterogenitását mutatja. A roma származást a korábbiakhoz hasonlóan becslésként veszem figyelembe. 


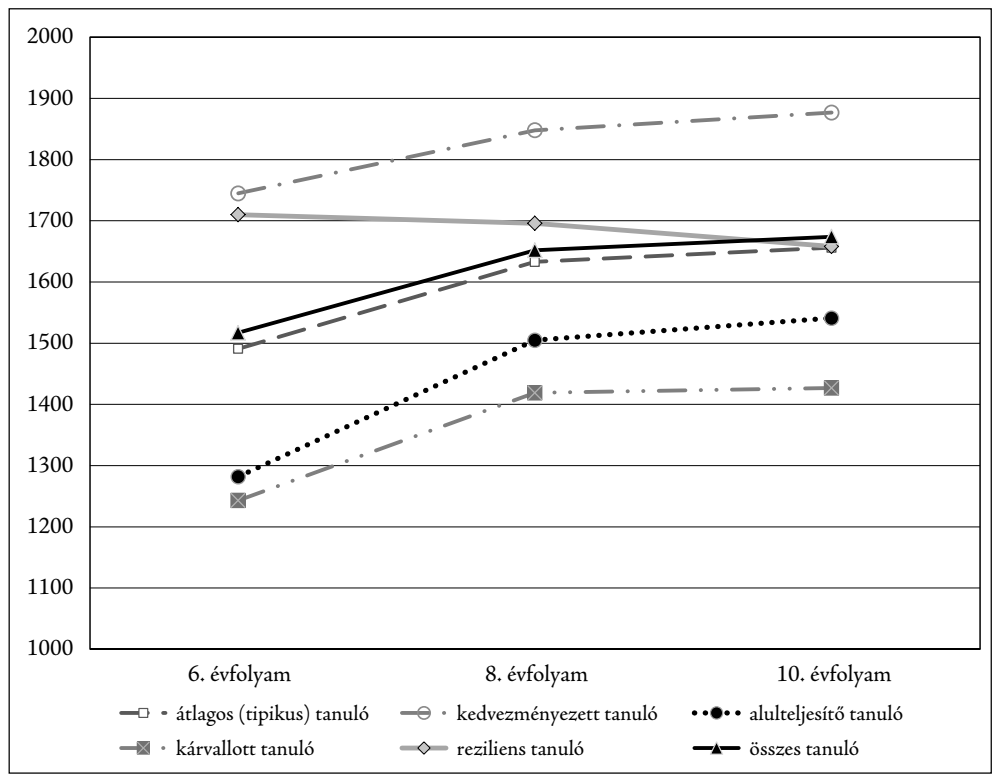

8. ábra: Matematika kompetenciaeredmények átlaga az egyes tanulói csoportok szerint, 6., 8. és 10. évfolyam $(N=81595,75355,67680)$

kategorizálva olvashatók le az összefüggések. A kárvallott tanulók és reziliens tanulók körében egyaránt igaz, hogy a lemorzsolódó vagy a lemorzslódással kapcsolatban nagy kockázattal jellemezhető tanulók aránya egyre magasabb, minél nagyobb pontossággal becsüljük a roma származást, illetve minél alacsonyabb mértékü CSHI-t veszünk figyelembe. Ugyanakkor a legalacsonyabb CSHI-vel rendelkezők rétegében a roma származás becslésének nincs szignifikáns hatása. Azaz a legalacsonyabb státuszúak esetében a roma származás már nem befolyásoló tényező, az ennél magasabb státuszúak körében pedig igen: nemcsak a státusz, hanem a roma származás is erősen rontja a sikeres továbbhaladás esélyét - a tanulási teljesítménytől függetlenül. A reziliens tanulóknál a származás hatása valamivel markánsabb: státusztól függetlenül egy jó teljesítményű roma tanulónak kisebb az esélye a tanulási pályán maradásnak, mint a hasonló státuszú nem roma tanulónak.

Ugyancsak érdemes röviden kitérni arra, hogy a reziliens tanulóknak - amennyiben folyamatosan továbbhaladnak későbbi tanulási útjukon - hogyan alakult a teljesítményük. A tanulói kategorizálástól függetlenül az összes folyamatosan továbbhaladó tanulóra igaz, hogy kisebb-nagyobb mértékben ugyan, de teljesítményük javult a hatodik és a nyolcadik évfolyam között (8. ábra). Két évfolyammal később már nem látszik a trend folytatása, igaz, romló tendencia sem. Az egyes tanulói csoportok nagyon hasonlóan viselkednek, kivételt a reziliensek jelentenek: az ő teljesítményük (folyamatos továbbhaladás mellett!) romlott, és a tizedik évfolyamra lényegében azonos lett a tipikus (átlagos) tanulók teljesítményével. Ez alapján úgy tünik, a reziliencia nem tartós jelenség. Ennek okának feltárása feltehetően egy másik elemzésnek a feladata, annyit azonban már most előrebocsáthatunk, hogy az intézménytípusnak feltehetően van szerepe a válaszban. Ha összevetjük a tizedik évfolyamos kompetenciaeredményeket a kedvezményezett és a reziliens tanulói csoportban (azaz akik hasonlóan jól teljesítettek hatodik évfolyamon) intézménytípus szerint, látható, hogy bár minden intézménycsoportban van eltérés, az 


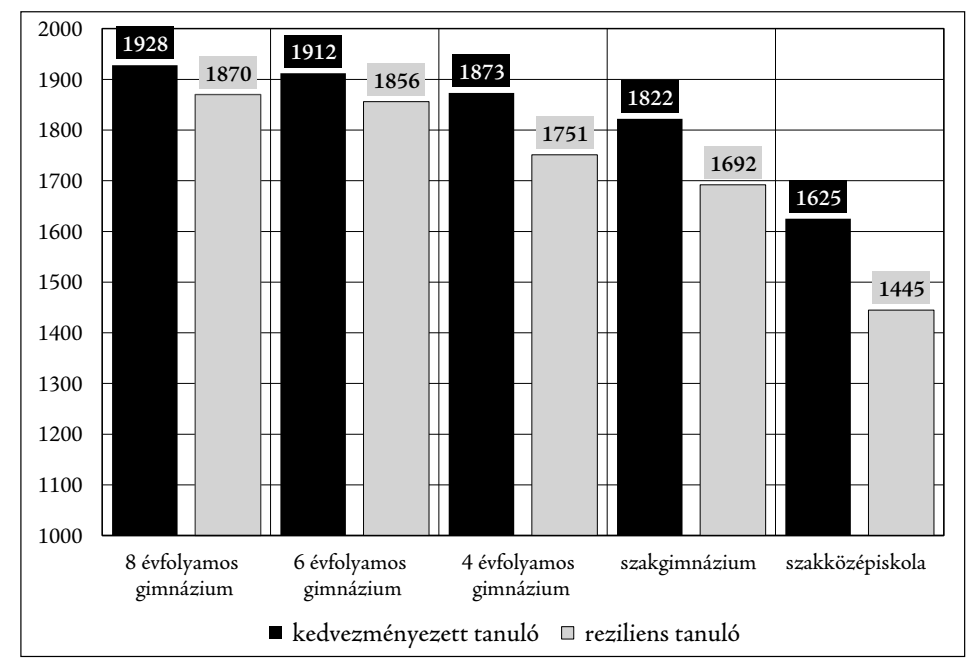

9. ábra: 10. évfolyamos kompetenciaeredmények a kedvezményezett és a reziliens tanulók között intézménytípusonként $(N=67680)$

olló igazából a négy évfolyamos gimnáziumtól számítva nyílik szét (9. ábra). Azaz úgy tűnik, egyelöre csak a szerkezetváltó gimnáziumok képesek arra, hogy ha egy reziliens tanuló bekerül tanulóik közé, az meg is őrizze kimagasló teljesítményét.

\section{Összefoglalás}

A tanulási utakat az OKM 2011-2017. évi tanulói adatbázisainak összekapcsolása segítségével vázoltam föl. A másodelemzés két tipizálási logikát követett. Először is, a tanulói pályaút folyamatosságát tekintve négy csoportba soroltam a tanulókat: folyamatosan továbbhaladók (73\%), évismétlők (10\%), lemorzsolódás kapcsán magas rizikófaktorúak (11\%) és lemorzsolódók (5\%). A lemorzsolódók és az ezzel kapcsolatos magas rizikófaktor néhány intézményi jellemzővel, a tanulók teljesítményével, túlkorosságukkal, szociális hátterükkel, tanulási nehézségeikkel és (közvetett módon becsülve) származásukkal függ össze. A tipizálás második logikája szerint a társadalmi háttér és a teljesítmény egy kiragadott mutatója segítségével öt tanulói csoportot különítettem el. A tanulói populáció legnagyobb hányada (42\%) mindkét dimenzió szerint tipikus (átlagos) tanuló, 17 százaléka kedvezményezett, 16 százaléka kárvallott, 5 százaléka alulteljesítő és 4 százaléka reziliens (további 17 százaléka pedig besorolatlan). Az alulteljesítők az átlagos tanulók arányával közel megfelelő mértékben haladnak tovább folyamatosan tanulási útjukon, míg a reziliensek körében komoly kockázata van a lemorzsolódásnak. Adataink szerint a kedvezményezett tanulók „kisajátítják” a szerkezetváltó gimnáziumokat, illetve ettől függetlenül is jellemző, hogy többségük a hagyományos gimnáziumokban tanul tovább. $\mathrm{A} z$ átlagos (tipikus) tanulók zöme a szakképzésbe kerül, a kárvallottak legnagyobb hányada pedig érettségit nem nyújtó szakközépiskolai intézménytípusban tanul tovább. A reziliens tanulók a tipikus (átlagos) tanulók továbbtanulási paramétereitől is elmaradnak, azaz a szelekciós folyamatban a társadalmi háttér erősebb befolyásoló erővel bír, mint a teljesítmény. Nagy területi különbségek jellemzők az egyes tanulói csoportok arányait tekintve: míg a kedvezményezett tanulók Budapesten és agglomerációjában, valamint 
a vidéki egyetemi centrumvárosokban; a kárvallottak az ország gazdasági-társadalmi szempontból kedvezőtlenebb térségeiben felülreprezentáltak. Jellemző, hogy a kedvezményezett és az alulteljesítő tanulók nagyobb, a kárvallott és reziliens tanulók pedig kisebb eséllyel tanultak egyházi fenntartású iskolákban hatodik évfolyamon (2011-ben). A kárvallott és a reziliens tanulók esetében a továbbhaladást leginkább a társadalmi státusz és a származás határozza meg. A legkedvezőtlenebb státuszúak továbbhaladása származástól független, de jellemző, hogy minél kedvezőbb státuszú egy tanuló (de sosem kedvező státuszú) valaki, annál inkább felértékelődik a származása: ha nagy valószínűséggel roma származású, akkor nagyobb eséllyel kerül a továbbhaladás szempontjából veszélyeztetettek közé. A reziliens tanulóknál ez a hatás erősebb, azaz a társadalmi mobilitás iskolai dimenziójában a roma származásúak helyzete nehezebb - pont abban a rétegben, ami a társadalmi középhez (átlaghoz) áll a legközelebb. Ráadásul, a reziliens tanulók későbbi teljesítménye akkor marad csak közel a kedvezményezett tanulók teljesítményéhez, ha szerkezetváltó gimnáziumba kerülnek, de ennek esélye csak keveseknek adatik meg.

\section{IRODALOM}

Agasisti, T., Avvisati, F., Borgonovi, F. \& Longobardi, S. (2018) Academic Resilience: What Schools and Countries Do to Help Disadvantaged Students Succeed in Pisa. OECD Working Paper No. 167. Paris, OECD Publishing.

Andor M. \& Liskó I. (1999) Iskolaválasztás és mobilitás. Iskolakultúra-könyvek 3., https:// mek.oszk.hu/03600/03672

Balázsi I., Balkányi P., Ostorics L., Palincsár I., Rábainé Sz. A., Szepesi I., Szipőcsné Krolopp J. \& Vadász CS. (2014) Az Országos Kompetenciamérés tartalmi keretei. Budapest, Oktatási Hivatal.

Csüllög K., Lannert, J. \& Zempléni, A. (2015) Számít a pedagógus és az iskola! A felülemelkedő (reziliens) tanulók teljesítményét befolyásoló tényezők az Országos kompetenciamérés adatai alapján. Budapest, Oktatási Hivatal.

Fehérvári A. (2015) Lemorzsolódás és a korai iskolaelhagyás trendjei. Neveléstudomány, Vol. 3. No. 3. pp. 31-47.

Hajdú T., Kertesi G. \& Kézdi G. (2014) Roma fiatalok a középiskolában. Beszámoló a TÁRKI Életpálya-felmérésének 2006 és 2012 közötti hullámaiból. Munkagazdaságtani Füzetek (BWP), 7, Magyar Tudományos Akadémia Közgazdaság- és Regionális Tudományi Kutatóközpont, Közgazdaság-tudományi Intézet, Budapesti Corvinus Egyetem, Emberi Erőforrások Tanszék. Letölthető: http://old.tarki.hu/adatbank-h/kutjel/pdf/ b334.pdf [Letöltve: 2019. 10. 01.]

Hörich B. (2018) Mobilitási szándékok és reziliencia. Educatio, Vol. 27. No. 4. pp. 714726.

Kertesi G.\& Kézdi G. (2010) Iskolázatlan szülők gyermekei és roma fiatalok a középiskolában. Beszámoló az Educatio Életpálya-felvételének 2006 és 2009 közötti hullámaiból. In: Kolosi T. \& Tóth I. Gr. (eds) Társadalmi Riport. Budapest, Tárki. pp. 371-407.

OECD (2010) PISA 2009 Results: What Students Know and Can Do - Student Performance in Reading, Mathematics and Science. Vol. I. PISA. Paris, OECD Publishing.

OECD (2013) PISA 2012 Results. Excellence through Equity. Giving Every Student the Chance to Succeed. Vol. II. PISA. Paris, OECD Publishing. 
OECD (2016) PISA 2015 Results. Excellence and Equity in Education. Vol. I. PISA. Paris, OECD Publishing.

OH (2012) Oktatási Hivatal: Országos kompetenciamérés. Technikai leírás. Letölthető: https://www.oktatas.hu/pub_bin/dload/kozoktatas/meresek/unios_tanulmanyok/ OKM_Technikaileiras.pdf

Papp Z. A. (2015) A méltányosság mérési lehetőségei. Középiskolai Kiadvány IV.

Révai N. (2015) Méltányosság az oktatásban - miről beszélünk? In: B. Tier N. (ed.) Alma a fán. Iskolavezetök a méltányos oktatásért. Budapest, Tempus. pp. 10-29.

Szemerszki M. (2016) A tanulói továbbhaladás egyéni és intézményi jellemzői. In: Szemersziki M. (ed.) Hátrányos helyzet és iskolai eredményesség. Budapest, OFI. pp. 2951.

Tóth E., Fejes J. B., Patai J. \& Csapó B. (2016) Reziliencia a magyar oktatási rendszerben egy longitudionális program adatainak tükrében. Magyar Pedagógia, Vol. 116. No. 3. pp. 339-363.

A cikk a Creative Commons Attribution 4.0 International License (https://creativecommons.org/licenses/ by/4.0/) feltételei szerint publikált Open Access közlemény, melynek szellemében a cikk bármilyen médiumban szabadon felhasználható, megosztható és újraközölhető, feltéve, hogy az eredeti szerző és a közlés helye, illetve a CC License linkje és az esetlegesen végrehajtott módosítások feltüntetésre kerülnek. (SID_1) 